\title{
SKRINING DAN IDENTIFIKASI ISOLAT BAKTERI ENDOFIT UNTUK MENGENDALIKAN PENYAKIT HAWAR DAUN BAKTERI PADA BAWANG MERAH
}

\author{
Zurai Resti ${ }^{1}$, Trimurti Habazar ${ }^{2}$, Deddi Prima Putra ${ }^{3}, \&$ Nasrun $^{4}$ \\ ${ }^{1}$ Mahasiswa Pascasarjana Universitas Andalas, Padang, Sumatera Barat \\ Jl. Alang Lawas IV No. 33 Padang 25211 \\ ${ }^{2}$ Dosen Fakultas Pertanian Universitas Andalas, Padang, Sumatera Barat \\ ${ }^{3}$ Dosen Fakultas Farmasi Universitas Andalas, Padang, Sumatera Barat \\ ${ }^{4}$ Peneliti pada Balai Penelitian Tanaman Obat dan Aromatik, Laing Solok, Sumatera Barat \\ E-mail: zures_01@yahoo.com
}

\begin{abstract}
Screening and identification of endophytic bacteria to control bacterial leafblight disease on Shallot. The experiment was conducted in Laboratory and Green House, from January to June 2012. Laboratory experiment consisted of three steps: (1) isolation of endophytic bacteria from healthy onion roots, (2)In planta/screening of endophytic isolates capable of reducing bacterial leaf blight disease, and (3) molecular identification of potential endophytic isolates. Treatments of in planta test were arranged in Completely Randomized Design. Collected isolates were tested for their capability in controlling bacterial leaf blight disease on shallot. The variables observed were disease incidence, disease severity, and shallot yield. The results showed that out of 82 isolates successfully isolated, 56 isolates $(68.29 \%)$ were Gram positive, and 26 isolate $(31.71 \%)$ were Gram negative. All isolates were HR negative and pathogenicity negative. Six endophytic isolates showed better performance in inducing resistance and increasing onion yield. Based on 16S rRNA sequence the six isolates were Bacillus cereus strain P14, Bacillus cereus strain Se07, Bacillus sp H1, Bacillus sp SJ1 and Serratia marcescens strain PPM4.
\end{abstract}

Key words: bacterial leaf blight, endophytic bacteria, Xanthomonas axonopodis pv allii, incidence, severity

\begin{abstract}
ABSTRAK
Skrining dan identifikasi isolat bakteri endofit untuk mengendalikan penyakit hawar daun bakteri pada bawang merah. Penelitian dilakukan di Laboratorium dan Rumah Kawat. Tahapan penelitian adalah (1) Isolasi bakteri endofit dari akar bawang yang sehat, disekitar tanaman sakit pada daerah endemik Hawar Daun Bakteri (HDB). (2) Seleksi isolat endofit yang memiliki kemampuan untuk mengendalikan penyakit HDB secara in planta, dan ( 3 ) Identifikasi isolat endofit terpilih secara molekular. Uji in planta untuk kemampuan induksi menggunakan Rancangan Acak Lengkap (RAL), parameter yang diamati adalah persentase serangan, intensitas serangan, dan berat umbi. Hasil penelitian diperoleh 82 isolat bakteri endofit, 56 isolat $(68,29 \%)$ adalah Gram positif, dan 26 isolat $(31,71 \%)$ adalah Gram negatif. Semua isolat HR negatif dan patogenisitas negatif. Enam isolat endofit memiliki kemampuan yang lebih baik untuk menginduksi ketahanan bawang merah terhadap HDB dan meningkatkan berat umbi bawang. Berdasarkan identifikasi molekular dengan 16S rRNA, enam isolat tersebut memiliki kemiripan dengan Bacillus cereus P14, Bacillus cereus Se07, Basillus sp H1, Bacillus sp SJ1 dan Serratia marcescens PPM4
\end{abstract}

Kata kunci: hawar daun bakteri, bakteri endofit, Xanthomonas axonopodis pv allii, kejadian, keparahan

\section{PENDAHULUAN}

Tanaman bawang merah merupakan komoditas unggulan Nasional, sehingga berbagai program dan kegiatan dilakukan untuk meningkatkan produksinya. Produktivitas bawang merah Nasional tahun 2009, 2010, dan 2011 berturut-turut sebanyak 9,28 ton/ha, 9,57 ton/ ha, dan 9,54 ton/ha (BPS, 2013). Produktivitas bawang merah ini masih tergolong rendah, dibandingkan potensi produksi optimum bawang merah yang dapat mencapai 16 ton/ha.

Salah satu penyebab rendahnya produktifitas bawang merah adalah serangan bakteri Xanthomonas axonopodis pv. allii (Xaa) penyebab penyakit hawar daun bakteri (HDB) seperti yang telah dilaporkan oleh Habazar et al. (2007). Hasil penelitian Resti et al. (2007) menyatakan bahwa penyakit hawar daun bakteri telah tersebar di daerah sentra produksi bawang merah di 
Sumatera Barat. Persentase serangan mencapai 100\% di Kab. Solok dan 39,62\% di Kab. Agam. Menurut Schwartz \& Gent (2006) kehilangan hasil (termasuk ukuran dan kualitas umbi) bisa mencapai $100 \%$, terutama bila kondisi lingkungan mendukung.

Pengendalian penyakit HDB dapat dilakukan melalui rotasi tanaman dengan tanaman bukan inang, menggunakan varietas tahan (Paulraj \& O'Garro, 1993), menggunakan benih sehat, sanitasi lahan, menghindari irigasi yang berlebihan. Pengendalian secara kimia menggunakan bakterisida (Schwartz \& Gent, 2006). Induksi ketahanan menggunakan Acibenzolar-s-metil, dan menggunakan agen hayati Pantoea aglomerans galur C9-1 (Actigard 50 WP) (Schwartz \& Gent, 2006). Hasil penelitian Habazar et al. (2007), menunjukkan bahwa rhizobakteria (RB) dari kelompok rhizosfir, rhizoplan dan endofit mampu menekan perkembangan penyakit HDB dan meningkatkan pertumbuhan tanaman bawang merah di rumah kaca dan dilapangan. Namun informasi rinci mengenai kemampuan bakteri endofit yang diintroduksi pada bawang merah dalam mengendalikan HDB masih terbatas.

Bakteri endofit dapat diisolasi dari bagian akar, batang, bunga, dan kotiledon. Bakteri dapat masuk melalui proses perkecambahan biji, akar-akar sekunder, stomata, atau melalui kerusakan yang terjadi pada daun. Di dalam jaringan tanaman bakteri berada di dalam sel, diruang antar sel, atau dalam jaringan pembuluh (Zinniel et al., 2002). Bakteri endofit sebagai agen biokontrol memiliki kelebihan dibandingkan agen biokontrol lainnya karena keberadaannya dalam jaringan tanaman, membuatnya mempunyai kemampuan bertahan terhadap tekanan biotik dan abiotik (Hallmann et al., 1997). Beberapa jenis bakteri endofit disamping sebagai agen biokontrol, juga sebagai pemacu pertumbuhan tanaman, dan mengimunisasi ketahanan tanaman terhadap patogen seperti Burkholderia sp. Strain PsJN mampu memacu pertumbuhan tanaman anggur (Vitis vinifera L.) (Compant et al., 2005). Informasi terbaru menyatakan bahwa Pseudmonad fluoresens yang bersifat endofit pada perakaran padi dan mampu memfikasi Nitrogen (Centre for Microbial and Plant Genetics 2006).

Penggunaan bakteri endofit untuk mengendalikan penyakit HDB pada tanaman bawang merah informasinya masih terbatas. Penemuan isolat bakteri endofit yang cocok untuk perlakuan benih bawang merah dalam mengendalikan $\mathrm{Xaa}$ penyebab penyakit HDB merupakan sumbangan yang sangat berarti, dalam bidang pengendalian hayati, dan pengembangan produksi biopestisida di Indonesia. Tujuan dari penelitian ini adalah.
Mendapatkan dan melakukan identifikasi isolat-isolat bakteri endofit indigenus yang mampu mengendalikan penyakit HDB dan meningkatkan hasil bawang merah.

\section{METODE PENELITIAN}

Isolasi Bakteri Endofit. Sampel jaringan tanaman sehat diambil dari daerah endemik penyakit HDB di Kabupaten Solok, dan Kabupaten Agam (Sumatera Barat). Pengambilan sampel dilakukan dengan pemilihan kebun secara purpossive randomized sampling, berdasarkan daerah sentra produksi bawang dan endemik penyakit hawar daun bakteri. Sampel yang diambil adalah akar beserta seluruh bagian tanaman sehat, dimasukkan ke dalam kantong kertas dan dibawa ke Laboratorium untuk diisolasi.

Bagian tanaman dicuci dengan akuades steril sebanyak dua kali. Sterilisasi permukaan dilakukan dengan menggunakan etanol $70 \%$ selama 5 menit, kemudian dicuci dengan akuades steril. Selanjutnya jaringan tanaman dihancurkan menggunakan lumpang dan mortal steril, kemudian dengan metode pengenceran suspensi bakteri $\left(10^{-3}, 10^{-4}\right)$ di biakkan dalam medium Nutrien Agar (NA), dan diinkubasi selama 48 jam. Isolat yang tumbuh diberi label dan dipindahkan dalam vial Eppendorf (vol $1 \mathrm{ml}$ ) berisi ekuades steril dan disimpan untuk pengujian berikutnya.

Semua isolat dimurnikan, kemudian dikarakterisasi morfologi, pengujian Gram menggunakan $\mathrm{KOH} 3 \%$ (Schaad \& Stall, 2001), serta Reaksi Hipersensitif pada daun tembakau (Klement et al., 1990). Isolat yang akan digunakan pada pengujian berikutnya adalah isolat yang bukan patogen yang ditandai dengan sifat HR yang (-).

Uji In planta. Penelitian dilakukan di Laboratorium Mikrobiologi Jurusan Hama dan Penyakit Tumbuhan dan Rumah Kawat Fakultas Pertanian Universitas Andalas Padang, dari bulan Januari sampai Juni 2012. Pengujian menggunakan Rancangan Acak Lengkap (RAL), perlakuan adalah 82 isolat bakteri endofit dengan 3 ulangan, dilanjutkan dengan uji jarak berganda Duncan pada taraf nyata $5 \%$. Media tanam yang digunakan adalah campuran tanah dan pupuk kandang $(2: 1 \mathrm{v} / \mathrm{v})$ yang disterilisasikan terlebih dahulu menggunakan metoda Tyndalisasi. Benih yang digunakan adalah benih bawang merah Kultivar Medan (rentan terhadap HDB). Benih dipilih yang memiliki ukuran yang hampir sama, bersih, tidak cacat, dan warna merah cerah. Sebelum ditanam benih dipotong $1 / 3$ bagian atas kemudian direndam dalam suspensi bakteri endofit dengan kepadatan inokulum $10^{8} \mathrm{sel} / \mathrm{ml}$ selama 15 menit, 
dikering anginkan, dan ditanam. Untuk kontrol benih direndam dengan akuades steril, dikeringanginkan kemudian ditanam dengan cara yang sama seperti pada perlakuan bakteri endofit.

Bakteri Xaa didapatkan dari koleksi Laboratorium Bakteriologi HPT, sebelum inokulasi isolat Xaa diremajakan pada medium Nutrien Glukosa Agar (NGA) dengan metode gores. Setelah tanaman berumur 14 hari dilakukan inokulasi patogen Xaa, dengan kerapatan inokulum $10^{6} \mathrm{sel} / \mathrm{ml}$. Inokulasi dilakukan dengan cara melukai permukaan daun bawang dengan jarum steril, kemudian suspensi Xaa dioleskan pada bagian yang dilukai tersebut dan tanaman disungkup dengan plastik bening. Tanaman diinkubasi selama \pm 7 hari dan tiap hari diamati gejala yang muncul. Pemeliharaan meliputi pemupukan dengan menggunakan pupuk buatan, penyiangan gulma dan pengendalian hama dengan cara mekanik.

Peubah yang diamati adalah persentase daun terserang $(\%)$, dan intensitas daun terserang (\%). Pengamatan hasil dengan mengukur berat basah dan berat kering tanaman. Pengamatan dimulai saat muncul gejala sampai panen dengan interval waktu tiga hari. Penghitungan berat basah dan berat kering umbi dilakukan setelah panen (umur 70 hari). Persentase serangan dihitung dengan rumus:

dengan:

$$
\mathrm{P}=\frac{\mathrm{X}}{\mathrm{Y}} \times 100 \%
$$

$\mathrm{P}=$ Persentase daun terserang,

$\mathrm{X}=$ Jumlah daun tanaman yang terserang,

$\mathrm{Y}=$ Jumlah daun yang diamati).

Intensitas serangan dihitung dengan rumus:

$$
\mathrm{I}=\frac{\sum\left(\mathrm{n}_{1} \times \mathrm{v}_{1}\right)}{\mathrm{Z} \times \mathrm{N}} \times 100 \%
$$

dengan:

$\mathrm{I}=$ Intensitas penyakit,

$\mathrm{n}_{1}=$ Jumlah daun dari tiap skala serangan,

$\mathrm{v}_{1}=$ Nilai skala dari tiap skala serangan,

$\mathrm{N}=$ Jumlah daun yang diamati,

$\mathrm{Z}=$ Nilai skala serangan tertinggi.

Nilai skala yang dipakai ditampilkan pada Tabel 1 . Efektivitas penggunaan isolat bakteri endofit dalam meningkatkan hasil umbi bawang merah dihitung dengan rumus berikut:

$$
\mathrm{E}=\frac{\mathrm{P}-\mathrm{K}}{\mathrm{K}} \times 100 \%
$$

dengan:

$\mathrm{E}=$ efektivitas,

$\mathrm{P}=$ perlakuan,

$\mathrm{K}=$ kontrol.

Efektivitas isolat bakteri endofit dalam menekanan penyakit hawar daun bakteri dihitung menggunakan rumus:

$$
\mathrm{E}=\frac{\mathrm{K}-\mathrm{P}}{\mathrm{K}} \times 100 \%
$$

dengan:

$\mathrm{E}=$ efektivitas,

$\mathrm{P}=$ perlakuan,

$\mathrm{K}=$ kontrol.

Identifikasi Isolat Endofit. Identifikasi dilakukan terhadap enam isolat bakteri endofit indigenus terpilih yang potensial untuk mengendalikan penyakit HDB pada bawang merah. Isolasi dan pemurnian DNA bakteri endofit dilakukan menggunakan Genomic DNA Mini Kit (Geneaid). DNA hasil isolasi selanjutnya diamplifikasi menggunakan pasangan primer $27 \mathrm{~F}$ (5'AGAGTTTGATCCTGGCTCAG 3') dan primer 42R

Tabel 1. Skala serangan penyakit hawar daun bakteri pada daun bawang (Habazar et al., 2007)

\begin{tabular}{clc}
\hline Skala & Tingkat serangan & Kerusakan \\
\hline 0 & Tidak gejala hawar & $0 \%$ \\
1 & Gejala hawar sedikit sekali & $>0-10 \%$ \\
2 & Gejala hawar sedikit & $>10-30 \%$ \\
3 & Gejala hawar sedang & $>30-50 \%$ \\
4 & Gejala hawar berat & $>50-70 \%$ \\
5 & Gejala hawar berat sekali & $>70 \%$ \\
\hline
\end{tabular}


(5' TACGGYTACCTTGTTACGACTT 3'). Kondisi awal PCR diatur pada suhu $94{ }^{\circ} \mathrm{C}$ selama 5 menit, selanjutnya diikuti dengan 35 siklus yang terdiri dari denaturasi pada suhu $94^{\circ} \mathrm{C}$ selama 3 menit, penempelan primer (annealing) pada suhu $55{ }^{\circ} \mathrm{C}$ selama 1 menit dan ekstensi pada suhu $72{ }^{\circ} \mathrm{C}$ selama 2 menit dan ekstensi akhir pada suhu $72{ }^{\circ} \mathrm{C}$ selama 10 menit. Hasil amplifikasi dielektroforesis menggunakan gel agarose $1 \%$ dalam buffer Tris Boric EDTA (TBE 0,5x) dan divisualisasi dibawah UV transilluminator. Hasil amplifikasi DNA menghasilkan pita berukuran \pm 1300 bp.

Produk PCR yang diperoleh selanjutnya disekuensing di PT Eijmen Indonesia Jakarta. Kegiatan sekuensing menggunakan prinsip kerja Sanger et al. (1997). Sekuensing dilakukan secara one read direction (satu arah) menggunakan salah satu primer yang dipergunakan pada proses amplifikasi. Keenam isolat endofit terpilih disekuensing dengan primer $27 \mathrm{~F}$ dan 42 $\mathrm{R}$. Data hasil sekuensing dicocokkan dengan data Gene Bank NCBI menggunakan BLAST pada http:// www.ncbi.nlm.nih.org.

\section{HASIL DAN PEMBAHASAN}

Isolasi Bakteri Endofit. Hasil isolasi bakteri endofit dari akar bawang merah sehat di daerah endemik HDB di Kabupaten Solok dan Kabupaten Agam diperoleh 82 isolat, 62 isolat diantaranya $(75,61 \%)$ berasal dari Kab. Solok, sedangkan 20 isolat lainnya $(24,39 \%)$ berasal dari Kab. Agam. Sebanyak 56 isolat $(68,29 \%)$ Gram positif dan 26 isolat $(31,70 \%)$ Gram negatif. Koloni dari isolat-isolat endofit tersebut memiliki morfologi dan warna yang berbeda-beda. Sifat fisiologinya berupa Gram dan reaksi hipersensitif ditampilkan pada Tabel 2. Beberapa penelitian sebelumnya telah melaporkan bahwa bakteri endofit dapat diisolasi dari berbagai tanaman, seperti Zinniel et al. (2002), yang mengisolasi 853 isolat endofit dari 27 jenis tumbuhan dari padang rumput dan 4 jenis tanaman agronomi. Terdapat variasi yang signifikan dari isolat bakteri endofit dari berbagai tanaman tersebut. Satu species tanaman dapat menjadi inang bagi berbagai jenis bakteri endofit (Strobel et al., 1993)

Di Kabupaten Solok lebih banyak isolat endofit yang dapat diisolasi karena memang sampel akar yang diperoleh lebih banyak dibandingkan dari Kabupaten Agam. Pada Kabupaten Agam sampel hanya didapatkan dari nagari Badorai Kecamatan Sungai pua, karena pada saat pengambilan sampel hanya pada Kecamatan tersebut dijumpai penanaman bawang merah yang cukup intensif. Sedangkan di Kabupaten Solok terdapat lahan penanaman bawang merah yang cukup luas di beberapa Nagari di Kecamatan Danau Kembar dan Kecamatan Lembah Gumanti, sehinnga didapatkan jumlah sampel yang lebih banyak. Menurut Zinniel et al. (2002), Keragaman isolat bakteri endofit indigenus dipengaruhi oleh spesifikasi inang, distribusi geografis, umur tanaman dan jenis tanaman inang.

Uji In planta. Pengujian in planta terhadap 82 isolat bakteri endofit dalam menekan serangan Xaa dapat dilihat pada Tabel 3. Tidak semua isolat mampu menekan serangan $\mathrm{Xaa}$, ini ditunjukkan dengan rata-rata efektifitas penekanan penyakit yang nilainya negatif (tidak mampu menekan penyakit dibandingkan dengan kontrol). Beberapa isolat mampu menekan persentase serangan penyakit secara signifikan yaitu isolat BD4.2E1 dengan persentase $8,33 \%$, intensitas 7,83 , isolat PU2E2 dengan persentase $9,39 \%$, intensitas $8,54 \%$, isolat SN1E4 dengan persentase $9,72 \%$, intensitas $9,00 \%$. isolat JB1E3 dengan persentase $10,11 \%$, intensitas $8,99 \%$, dibandingkan kontrol dengan persentase $23,84 \%$ dan intensitas $21,93 \%$. Efektifitas penekanan persentase serangan dan penekanan intensitas tertinggi pada isolat BD4.2E1 yaitu $65,05 \%$ untuk persentase serangan dan $64,30 \%$ untuk intensitas serangan dibandingkan kontrol. Isolat PU2E2 penekanan persentase serangan $60,61 \%$ penekanan intensitas $61,06 \%$, isolat SN1E4 penekanan persentase serangan $59,59 \%$ penekanan intensitas $58,96 \%$ dan isolat JB1E3 penekanan persentase 57,59\%, penekanan intensitas $59,01 \%$.

Bakteri endofit dapat digunakan sebagai agen pengendali hayati yang lebih baik dibandingkan dengan kelompok bakteri dari rhizospir karena tidak berkompetisi dalam hal nutrisi dan lingkungan mikro tempat hidupnya (Reiter et al., 2002). Hasil pengujian 82 isolat endofit indigenus Sumatera Barat yang diintroduksikan pada benih bawang Kultivar Medan menunjukkan bahwa beberapa isolat endofit mampu menghambat perkembangan penyakit HDB dengan rata-rata kemampuan penekanan persentase penyakit tertinggi $60,06 \%$ (Tabel 3), yaitu pada isolat BD4.2E1. Hasil penelitian ini menunjukkan bahwa kemampuan isolat endofit indigenus cukup tinggi untuk menurunkan serangan penyakit HDB di rumah kaca, dibandingkan beberapa hasil penelitian yang mengintroduksi beberapa jenis agen hayati, seperti penggunaan Pseudomonas fluorescen dapat menurunkan serangan Bean Common Mosaic Potyvirus (BCMV) pada kacang buncis dari 53\% pada kontrol menjadi 10\% (Kumar, 2005). Aplikasi formulasi komersil Pantoea agglomerans galur C9-1 
Tabel 2. Keragaman sifat fisiologis isolat bakteri endofit indigenus yang diisolasi dari akar bawang merah di Kab. Agam dan Kab. Solok

\begin{tabular}{|c|c|c|c|c|c|c|c|c|c|}
\hline No & Isolat & Asal isolat & Uji Gram & HR & No & Isolat & Asal isolat & Uji Gram & HR \\
\hline 1 & BD1 E1 & Agam & + & - & 42 & SN1E & Solok & - & - \\
\hline 2 & BD1.1 E2 & Agam & + & - & 43 & SN1E2 & Solok & + & - \\
\hline 3 & BD1.2E2 & Agam & + & - & 44 & SN1E3 & Solok & - & - \\
\hline 4 & BD1.2E3 & Agam & + & - & 45 & SN1E4 & Solok & + & - \\
\hline 5 & $\mathrm{BD} 1.2 \mathrm{E} 4$ & Agam & + & - & 46 & SN2E & Solok & + & - \\
\hline 6 & BD1.3E2 & Agam & + & - & 47 & SN2E2 & Solok & + & - \\
\hline 7 & BD1.3E3 & Agam & + & - & 48 & SN2E3 & Solok & + & - \\
\hline 8 & BD2E1 & Agam & + & - & 49 & JB1E & Solok & - & - \\
\hline 9 & BD2E2 & Agam & + & - & 50 & JB1E2 & Solok & + & - \\
\hline 10 & BD2.1E1 & Agam & + & - & 51 & JB1E3 & Solok & - & - \\
\hline 11 & BD2.2E1 & Agam & + & - & 52 & STP1E2 & Solok & + & - \\
\hline 12 & BD2.2E3 & Agam & + & - & 53 & STP1E3 & Solok & - & - \\
\hline 13 & BD2.2E5 & Agam & + & - & 54 & STP1E4 & Solok & + & - \\
\hline 14 & BD2.2E6 & Agam & + & - & 55 & STP1E5 & Solok & - & - \\
\hline 15 & BD3E1 & Agam & + & - & 56 & TL1E1 & Solok & - & - \\
\hline 16 & BD3.1E1 & Agam & + & - & 57 & TL1E2 & Solok & - & - \\
\hline 17 & BD3.1E2 & Agam & + & - & 58 & TL1E2.1 & Solok & - & - \\
\hline 18 & BD4E1 & Agam & + & - & 59 & TL1E2.3 & Solok & - & - \\
\hline 19 & BD4.1E2 & Agam & + & - & 60 & TL1E4 & Solok & - & - \\
\hline 20 & BD4.2E1 & Agam & + & - & 61 & TL2E1 & Solok & + & - \\
\hline 21 & LKE & Solok & + & - & 62 & TL2E2 & Solok & + & - \\
\hline 22 & LKE2 & Solok & + & - & 63 & TL2E2.1 & Solok & + & - \\
\hline 23 & LKE3 & Solok & + & - & 64 & TL2E2.3 & Solok & + & - \\
\hline 24 & LL1E2 & Solok & + & - & 65 & TL3E1 & Solok & - & - \\
\hline 25 & LL1E3 & Solok & + & - & 66 & TL3E1.2 & Solok & - & - \\
\hline 26 & $\mathrm{SS} 2 \mathrm{E}$ & Solok & + & - & 67 & TL3E2 & Solok & - & - \\
\hline 27 & RD1E1 & Solok & + & - & 68 & TL3E2.1 & Solok & + & - \\
\hline 28 & RD1E2 & Solok & + & - & 69 & TP1E1 & Solok & + & - \\
\hline 29 & RD2E2 & Solok & + & - & 70 & TP1E2 & Solok & - & - \\
\hline 30 & PK1E & Solok & + & - & 71 & TP1E2.2 & Solok & - & - \\
\hline 31 & PK2E2 & Solok & - & - & 72 & TP2E1 & Solok & + & - \\
\hline 32 & PK2E3 & Solok & - & - & 73 & TP2E1.2 & Solok & - & - \\
\hline 33 & PK2E4 & Solok & + & - & 74 & TP2E1.3 & Solok & - & - \\
\hline 34 & PU1E2 & Solok & + & - & 75 & TP2E2 & Solok & - & - \\
\hline 35 & PU1E3 & Solok & + & - & 76 & TP2E2.1 & Solok & - & - \\
\hline 36 & PU2E1 & Solok & + & - & 77 & TP3E1 & Solok & + & - \\
\hline 37 & PU2E2 & Solok & + & - & 78 & TP3E2 & Solok & - & - \\
\hline 38 & ULG1E1 & Solok & + & - & 79 & TP4E1 & Solok & - & - \\
\hline 39 & ULG1E2 & Solok & - & - & 80 & TP4E1.2 & Solok & + & - \\
\hline 40 & ULG1E3 & Solok & + & - & 81 & TP4E2.1 & Solok & + & - \\
\hline 41 & ULG1E4 & Solok & - & - & 82 & TP4E5 & Solok & + & - \\
\hline
\end{tabular}

dan Pseudomonas fluorescen galur A506 dapat menurunkan severitas penyakit HDB (Gent \& Schwartz, 2005).
Kemampuan peningkatan berat umbi bawang merah dapat dilihat pada Tabel 4. Isolat bakteri endofit dengan berat basah dan berat kering umbi yang 
Tabel 3. Persentase, intensitas dan efektifitas penekanan penyakit HDB pada bawang merah yang diintroduksi bakteri endofit

\begin{tabular}{|c|c|c|c|c|c|c|}
\hline No & Isolat & Persentase $(\%)$ & Efektifitas (\%) & Isolat & Intensitas (\%) & Efektifitas (\%) \\
\hline 1 & TL3E2 & $27,82 \mathrm{a}$ & $-16,69$ & STP1E4 & $27,55 \mathrm{a}$ & $-25,63$ \\
\hline 2 & BD3E1 & $25,15 \mathrm{ab}$ & $-5,49$ & kontrol & $21,93 \mathrm{ab}$ & 0,00 \\
\hline 3 & LKE2 & $25,09 \mathrm{ab}$ & $-5,24$ & TL3E2 & $21,52 \mathrm{ab}$ & 1,87 \\
\hline 4 & TP3E1 & $24,82 \mathrm{ab}$ & $-4,11$ & LKE2 & $20,59 \mathrm{ab}$ & 6.11 \\
\hline 5 & RD2E2 & $24,50 \mathrm{ab}$ & $-2,77$ & SN2E & $19,71 \mathrm{ab}$ & 10,12 \\
\hline 6 & SN2E & $24,41 \mathrm{ab}$ & $-2,39$ & TL3E1 & $19,28 \mathrm{ab}$ & 12,08 \\
\hline 7 & TL3E1 & $23,89 \mathrm{ab}$ & $-0,21$ & BD3E1 & $18,81 \mathrm{ab}$ & 14,23 \\
\hline 8 & Kontrol & $23,84 \mathrm{ab}$ & 0,00 & TP2E1 & $18,66 \mathrm{ab}$ & 14,91 \\
\hline 9 & $\mathrm{BD} 2 \mathrm{E} 2$ & $23,33 \mathrm{ab}$ & 2,14 & RD2E2 & $18,39 \mathrm{ab}$ & 16,14 \\
\hline 10 & TL1E4 & $23,07 \mathrm{ab}$ & 3,23 & BD1.1E2 & $18,39 \mathrm{ab}$ & 16,14 \\
\hline 11 & TL2E2 & $22,62 \mathrm{ab}$ & 5,12 & ULG1E2 & $18,14 \mathrm{ab}$ & 17,28 \\
\hline 12 & ULG1E1 & $22,45 \mathrm{ab}$ & 5,83 & ULG1E1 & $18,08 \mathrm{ab}$ & 17,56 \\
\hline 13 & TP3E2 & $22,26 \mathrm{ab}$ & 6,63 & BD1E1 & $18,03 \mathrm{ab}$ & 17,78 \\
\hline 14 & RD1E1 & $22,05 \mathrm{ab}$ & 7,51 & RD1E1 & $17,93 \mathrm{ab}$ & 18,24 \\
\hline 15 & TP2E1 & $22,02 \mathrm{ab}$ & 7,63 & TL1E2.3 & $17,78 \mathrm{ab}$ & 18,92 \\
\hline 16 & BD1E1 & $21,27 \mathrm{ab}$ & 10,78 & TL3E2.1 & $17,66 \mathrm{ab}$ & 19,47 \\
\hline 17 & ULG1E2 & $21,23 \mathrm{ab}$ & 10,95 & TL1E2.1 & $17,63 \mathrm{ab}$ & 19,61 \\
\hline 18 & BD2E1 & $21,18 \mathrm{ab}$ & 11,16 & TP3E1 & $17,46 \mathrm{ab}$ & 20,38 \\
\hline 19 & TP1E2 & $21,08 \mathrm{ab}$ & 11,58 & PU1E3 & $17,25 \mathrm{ab}$ & 21,34 \\
\hline 20 & BD1.1E2 & $20,29 a b$ & 14,89 & TL2E2 & $17,11 \mathrm{ab}$ & 21,98 \\
\hline 21 & LL1E2 & $20,27 \mathrm{ab}$ & 14,97 & BD2E2 & $16,94 \mathrm{ab}$ & 22,75 \\
\hline 22 & TP2E2 & $20,07 \mathrm{ab}$ & 15,81 & LL1E2 & $16,88 \mathrm{ab}$ & 23,03 \\
\hline 23 & TL3E2.1 & $19,71 \mathrm{ab}$ & 17,32 & TP1E2 & $16,86 \mathrm{ab}$ & 23,12 \\
\hline 24 & PK2E2 & $19,41 \mathrm{ab}$ & 18,58 & TL1E4 & $16,71 \mathrm{ab}$ & 23,80 \\
\hline 25 & TL1E2.1 & $19,27 \mathrm{ab}$ & 19,17 & TP4E1.2 & $16,41 \mathrm{ab}$ & 25,17 \\
\hline 26 & PU1E3 & $19,20 \mathrm{ab}$ & 19,46 & TP2E2 & $16,09 \mathrm{ab}$ & 26,63 \\
\hline 27 & SN2E2 & $18,41 \mathrm{ab}$ & 22,78 & PK2E2 & $15,83 \mathrm{ab}$ & 27,82 \\
\hline 28 & BD4E1 & $17,37 \mathrm{ab}$ & 27,14 & SN2E2 & $15,72 \mathrm{ab}$ & 28,32 \\
\hline 29 & TP4E1.2 & $16,99 \mathrm{ab}$ & 28,73 & $\mathrm{BD} 2 \mathrm{E} 1$ & $15,66 \mathrm{ab}$ & 28,59 \\
\hline 30 & TL1E2 & $16,66 \mathrm{ab}$ & 30,12 & TP3E2 & $15,31 \mathrm{ab}$ & 30,19 \\
\hline 31 & LKE & $16,51 \mathrm{ab}$ & 30,75 & TP2E1.3 & $15,11 \mathrm{ab}$ & 31,10 \\
\hline 32 & PK1E & $16,33 \mathrm{ab}$ & 31,50 & BD4E1 & $14,76 \mathrm{ab}$ & 32,69 \\
\hline 33 & TL2E1 & $16,26 \mathrm{ab}$ & 31,80 & BD1.3E3 & $14,74 \mathrm{ab}$ & 32,79 \\
\hline 34 & PU1E2 & $16,13 \mathrm{ab}$ & 32,34 & LKE & $14,09 \mathrm{ab}$ & 35,75 \\
\hline 35 & SN1E2 & $15,18 \mathrm{ab}$ & 36,33 & TP4E2.1 & $13,96 \mathrm{ab}$ & 36,34 \\
\hline 36 & TP2E1.3 & $15,11 \mathrm{ab}$ & 36,62 & $\mathrm{BD} 2.2 \mathrm{E} 1$ & $13,86 \mathrm{ab}$ & 36,80 \\
\hline 37 & $\mathrm{BD} 2.2 \mathrm{E} 1$ & $15,08 \mathrm{ab}$ & 36,74 & BD2.2E5 & $13,78 \mathrm{ab}$ & 37,16 \\
\hline 38 & BD3.1E1 & $15,05 \mathrm{ab}$ & 36,87 & PU1E2 & $13,77 \mathrm{ab}$ & 37,21 \\
\hline 39 & TP4E2.1 & $15,00 \mathrm{ab}$ & 37,08 & SN1E2 & $13,56 \mathrm{ab}$ & 38,17 \\
\hline 40 & TP1E1 & $14,92 \mathrm{ab}$ & 37,42 & $\mathrm{BD} 2.2 \mathrm{E} 3$ & $13,35 \mathrm{ab}$ & 39,12 \\
\hline 41 & TP4E1 & $14,83 \mathrm{ab}$ & 37,79 & RD1E2 & $13,33 \mathrm{ab}$ & 39,22 \\
\hline 42 & BD1.3E3 & $14,74 \mathrm{ab}$ & 38,17 & TL1E2 & $13,33 \mathrm{ab}$ & 39,22 \\
\hline 43 & TL1E1 & $14,67 \mathrm{ab}$ & 38,46 & BD3.1E1 & $13,18 \mathrm{ab}$ & 39,90 \\
\hline 44 & SS2E & $14,47 \mathrm{ab}$ & 39,30 & TL2E1 & $13,06 \mathrm{ab}$ & 40,45 \\
\hline 45 & BD2.2E5 & $14,45 \mathrm{ab}$ & 39,39 & ULG1E3 & $13,03 \mathrm{ab}$ & 40,58 \\
\hline 46 & TL3E1.2 1 & $14,35 \mathrm{ab}$ & 39,81 & TL3E1.2 & $12,98 \mathrm{ab}$ & 40,81 \\
\hline
\end{tabular}


Tabel 3. lanjutan

\begin{tabular}{|c|c|c|c|c|c|c|}
\hline 47 & $\mathrm{BD} 2.2 \mathrm{E} 3$ & $13,87 \mathrm{ab}$ & 41,82 & BD3.1E2 & $12,91 \mathrm{~b}$ & 41,13 \\
\hline 48 & BD3.1E2 & $13,59 \mathrm{ab}$ & 42,99 & PK1E & $12,68 \mathrm{~b}$ & 42,18 \\
\hline 49 & RD1E2 & $13,57 \mathrm{ab}$ & 43,08 & TP4E1 & $12,61 \mathrm{~b}$ & 42,50 \\
\hline 50 & ULG1E3 & $13,57 \mathrm{ab}$ & 43,08 & $\mathrm{SS} 2 \mathrm{E}$ & $12,61 \mathrm{~b}$ & 42,50 \\
\hline 51 & SN1E & $13,52 \mathrm{ab}$ & 43,29 & BD1.3E2 & $12,40 \mathrm{~b}$ & 43,46 \\
\hline 52 & TP2E1.2 & $13,50 \mathrm{ab}$ & 43,37 & SN1E3 & $12,37 \mathrm{~b}$ & 43,59 \\
\hline 53 & TL1E2.3 & $13,35 \mathrm{ab}$ & 44,00 & TL1E1 & $12,25 \mathrm{~b}$ & 44,14 \\
\hline 54 & SN1E3 & $13,17 \mathrm{ab}$ & 44,76 & ULG1E4 & $12,13 \mathrm{~b}$ & 44,69 \\
\hline 55 & BD2.1E1 & $12,99 \mathrm{ab}$ & 45,51 & TP2E2.1 & $12,08 \mathrm{~b}$ & 44,92 \\
\hline 56 & TP2E2.1 & $12,98 \mathrm{ab}$ & 45,55 & BD1.2E2 & $12,07 \mathrm{~b}$ & 44,96 \\
\hline 57 & BD1.3E2 & $12,94 \mathrm{ab}$ & 45,72 & TL2E2.1 & $11,96 \mathrm{~b}$ & 45,46 \\
\hline 58 & BD4.1E2 & $12,93 \mathrm{ab}$ & 45,76 & TP2E1.2 & $11,88 \mathrm{~b}$ & 45,83 \\
\hline 59 & BD1.2E2 & $12,83 \mathrm{ab}$ & 46,18 & BD2.1E1 & $11,84 \mathrm{~b}$ & 46,01 \\
\hline 60 & LKE3 & $12,63 \mathrm{ab}$ & 47,02 & LKE3 & $11,62 \mathrm{~b}$ & 47,01 \\
\hline 61 & TL2E2.1 & $12,63 \mathrm{ab}$ & 47,02 & BD4.1E2 & $11,61 \mathrm{~b}$ & 47,06 \\
\hline 62 & STP1E4 & $12,55 \mathrm{ab}$ & 47,36 & SN2E3 & $11,33 \mathrm{~b}$ & 48,34 \\
\hline 63 & TP1E2.2 & $12,38 \mathrm{ab}$ & 48,07 & SN1E & $11,19 \mathrm{~b}$ & 48,97 \\
\hline 64 & $\mathrm{JB} 1 \mathrm{E}$ & $12,13 \mathrm{ab}$ & 49,12 & JB1E2 & $11,16 \mathrm{~b}$ & 49,11 \\
\hline 65 & JB1E2 & $11,96 \mathrm{ab}$ & 49,83 & BD2.2E6 & $10,95 \mathrm{~b}$ & 50,07 \\
\hline 66 & SN2E3 & $11,94 \mathrm{ab}$ & 49,92 & TL2E2.3 & $10,83 \mathrm{~b}$ & 50,62 \\
\hline 67 & TL2E2.3 & $11,93 \mathrm{ab}$ & 49,96 & STP1E3 & $10,74 \mathrm{~b}$ & 51,03 \\
\hline 68 & BD2.2E6 & $11,81 \mathrm{ab}$ & 50,46 & TP1E1 & $10,74 \mathrm{~b}$ & 51,03 \\
\hline 69 & PU2E1 & $11,60 \mathrm{ab}$ & 51,34 & PU2E1 & $10,73 \mathrm{~b}$ & 51,07 \\
\hline 70 & STP1E3 & $11,44 \mathrm{ab}$ & 52,01 & STP1E2 & $10,67 \mathrm{~b}$ & 51,35 \\
\hline 71 & TP4E5 & $11,34 \mathrm{ab}$ & 52,43 & LL1E3 & $10,25 \mathrm{~b}$ & 53,26 \\
\hline 72 & STP1E2 & $11,23 \mathrm{ab}$ & 52,89 & TP1E2.2 & $10,21 \mathrm{~b}$ & 53,44 \\
\hline 73 & BD1.2E3 & $11,11 \mathrm{ab}$ & 53,40 & BD1.2E3 & $10,11 \mathrm{~b}$ & 53,90 \\
\hline 74 & BD1.2E4 & $10,92 \mathrm{ab}$ & 54,19 & $\mathrm{JB} 1 \mathrm{E}$ & $10,03 \mathrm{~b}$ & 54,26 \\
\hline 75 & STP1E5 & $10,83 \mathrm{ab}$ & 54,57 & STP1E5 & $9,89 \quad b$ & 54,90 \\
\hline 76 & PK2E4 & $10,72 \mathrm{ab}$ & 55,03 & $\mathrm{BD} 1,2 \mathrm{E} 4$ & $9,66 \quad b$ & 55,95 \\
\hline 77 & ULG1E4 & $10,67 \mathrm{ab}$ & 55,24 & PK2E4 & $9,66 \quad b$ & 55,95 \\
\hline 78 & PK2E3 & $10,63 \mathrm{ab}$ & 55,41 & TP4E5 & $9,57 \quad b$ & 56,36 \\
\hline 79 & LL1E3 & $10,25 \mathrm{ab}$ & 57,01 & PK2E3 & $9,37 \quad b$ & 57,27 \\
\hline 80 & JB1E3 & $10,11 \mathrm{ab}$ & 57,59 & SN1E4 & $9,00 \quad b$ & 58,96 \\
\hline 81 & SN1E4 & $9,72 \quad b$ & 59,23 & JB1E3 & $8,99 \quad b$ & 59,01 \\
\hline 82 & PU2E2 & $9,39 \quad b$ & 60,61 & PU2E2 & $8,54 \quad b$ & 61,06 \\
\hline 83 & BD4.2E1 & $8,33 \quad b$ & 65,06 & BD4.2E1 & $7,83 \quad b$ & 64,30 \\
\hline
\end{tabular}

Angka-angka pada lajur yang sama yang diikuti oleh huruf kecil yang sama tidak berbeda nyata menurut uji jarak berganda Duncan pada $\alpha=0,05$.

signifikan adalah isolat SN2E2 dengan berat basah $121,98 \mathrm{~g}$ (peningkatan 281,66\%), berat kering 60,86 g (peningkatan $214,85 \%$ ) dibandingkan kontrol dengan berat basah 23,84 g dan berat kering 21,93 g. Isolat ULG1E2 dengan berat basah 105,77 g (peningkatan $230,94 \%$ ) berat kering $60,46 \mathrm{~g}$ (peningkatan $212,78 \%$ ). Empat isolat yang mampu menekan persentase dan intensitas penyakit secara signifikan juga dapat meningkatkan berat basah dan berat kering umbi. Isolat tersebut PU2E2 berat basah 70,79 g (peningkatan $121,50 \%$ ) berat kering 36,98 g (peningkatan 91,31\%), isolat SN1E4 berat basah 51,16 g (peningkatan 60,08\%) berat kering $36,55 \mathrm{~g}$ (peningkatan $89,08 \%$ ), isolat BD4.2E1 berat basah 45,59 g (peningkatan 42,65\%) 
Tabel 4. Berat basah, berat kering dan efektifitas peningkatan berat umbi bawang merah yang diintroduksi dengan bakteri endofit

\begin{tabular}{|c|c|c|c|c|c|c|}
\hline No & Isolat & Berat basah $(\mathrm{g})$ & Efektifitas (\%) & Isolat & Berat kering umbi (g) & Efektifitas $(\%)$ \\
\hline 1 & SN2E2 & $121,98 \mathrm{a}$ & 281,66 & SN2E2 & $60,86 \mathrm{a}$ & 214,85 \\
\hline 2 & ULG1E2 & $105,77 \mathrm{a}$ & 230,94 & ULG1E2 & 60,46 a & 212,78 \\
\hline 3 & PU2E2 & $70,79 \mathrm{~b}$ & 121,50 & PU2E2 & $36,98 \mathrm{~b}$ & 91,31 \\
\hline 4 & SN1E4 & $51,16 \mathrm{bc}$ & 60,08 & SN1E4 & $36,55 \mathrm{bc}$ & 89,08 \\
\hline 5 & BD4.2E1 & $45,59 \mathrm{bcd}$ & 42.65 & JB1E3 & $33,01 \mathrm{bcd}$ & 70,77 \\
\hline 6 & JB1E3 & $42,78 \mathrm{cde}$ & 33,85 & BD4.2E1 & 29,12 bcde & 50,65 \\
\hline 7 & TP2E1 & 41,73 cde & 30,57 & TP2E2.1 & 28,42 bcde & 47,03 \\
\hline 8 & PK2E2 & 40,64 cdef & 27,16 & ULG1E4 & 27,14 bcde & 40,40 \\
\hline 9 & BD1.3E2 & 40,24 cdef & 25,91 & TP1E2.2 & 26,70 bcde & 38,13 \\
\hline 10 & TL2E2.1 & 39,48 cdef & 23,53 & TL2E2.1 & 26,24 bcde & 35,75 \\
\hline 11 & LL1E2 & 38,39 cdef & 20,12 & BD1.2E3 & 26,08 bcde & 34,92 \\
\hline 12 & BD1.2E3 & 37,83 cdef & 18,37 & TP2E1 & 25,26 bcde & 30,68 \\
\hline 13 & TP2E2,1 & 37,06 cdef & 15,96 & $\mathrm{BD} 2 \mathrm{E} 2$ & 24,99 bcde & 29,28 \\
\hline 14 & TP1E1 & 37,01 cdef & 15,80 & BD1.3E2 & 24,48 bcde & 26,64 \\
\hline 15 & BD2E2 & 36,29 cdef & 13,55 & TL2E2 & 24,23 bcde & 25,35 \\
\hline 16 & TL2E2 & 36,15 cdef & 13,11 & PK2E4 & 24,02 bcde & 24,26 \\
\hline 17 & PK2E4 & 35,61 cdef & 11,42 & BD2.2E5 & 23,97 bcde & 24,00 \\
\hline 18 & TP2E2 & 35,31 cdef & 10,48 & TL1E2 & 23,82 bcde & 23,23 \\
\hline 19 & ULG1E4 & 35,13 cdef & 9,92 & ULG1E3 & 23,29 bcde & 20,49 \\
\hline 20 & PK2E3 & 34,20 cdef & 7,01 & PK2E2 & 22,86 bcde & 18,26 \\
\hline 21 & TP1E2.2 & 33,44 cdef & 4,63 & TP2E1,3 & 22,71 bcde & 17,49 \\
\hline 22 & BD2.2E5 & 33,04 cdef & 3,38 & BD3.1E2 & 22,57 bcde & 16,76 \\
\hline 23 & JB1E2 & 32,89 cdef & 2,91 & JB1E2 & 22,25 bcde & 15,11 \\
\hline 24 & Kontrol & 31,96 cdef & 0,00 & TP2E1.2 & 21,91 bcde & 13,35 \\
\hline 25 & STP1E2 & 31,51 cdef & $-1,41$ & STP1E5 & 21,75 bcde & 12,52 \\
\hline 26 & TL1E2 & 31,50 cdef & $-1,44$ & TP4E1 & 21,20 bcde & 9,67 \\
\hline 27 & TL3E1.2 & 31,23 cdef & $-2,28$ & $\mathrm{BD} 1.2 \mathrm{E} 4$ & 21,10 bcde & 9,16 \\
\hline 28 & PK1E & 30,65 cdef & $-4,10$ & TP2E2 & 20,54 bcde & 6,26 \\
\hline 29 & TP2E1.3 & 30,29 cdef & $-5,23$ & PK2E3 & 20,33 bcde & 5,17 \\
\hline 30 & TL2E2.3 & 30,06 cdef & $-5,94$ & PU1E3 & 20,33 bcde & 5,17 \\
\hline 31 & STP1E5 & 29,97 cdef & $-6,23$ & RD1E2 & 19,97 cde & 3,31 \\
\hline 32 & BD1.3E3 & 29,92 cdef & $-6,38$ & TP1E1 & $19,61 \mathrm{de}$ & 1,45 \\
\hline 33 & TP4E1 & 29,84 cdef & $-6,63$ & STP1E2 & $19,55 \mathrm{de}$ & 1,14 \\
\hline 34 & RD2E2 & 29,58 cdef & $-7,45$ & TL2E2.3 & $19,53 \mathrm{de}$ & 1,03 \\
\hline 35 & ULG1E3 & 29,24 cdef & $-8,51$ & STP1E3 & $19,41 \mathrm{de}$ & 0,41 \\
\hline 36 & $\mathrm{BD} 1.2 \mathrm{E} 4$ & 29,22 cdef & $-8,57$ & kontrol & $19,33 \mathrm{de}$ & 0,00 \\
\hline 37 & BD2.2E6 & 28,90 cdef & $-9,57$ & $\mathrm{BD} 2.2 \mathrm{E} 3$ & $19,24 \mathrm{de}$ & $-0,47$ \\
\hline 38 & BD3.1E2 & 28,85 cdef & $-9,73$ & PU2E1 & $19,05 \mathrm{de}$ & $-1,45$ \\
\hline 39 & TP4E2.1 & 28,83 cdef & $-9,79$ & SN1E3 & $18,72 \mathrm{de}$ & $-3,16$ \\
\hline 40 & PU1E3 & 28,58 cdef & $-10,58$ & TP4E2,1 & $18,63 \mathrm{de}$ & $-3,62$ \\
\hline 41 & TL1E2.1 & 28,55 cdef & $-10,67$ & TL2E1 & $18,48 \mathrm{de}$ & $-4,40$ \\
\hline 42 & TL1E1 & 28,42 cdef & $-11,08$ & RD2E2 & $18,42 \mathrm{de}$ & $-4,71$ \\
\hline 43 & STP1E4 & 27,55 cdef & $-13,80$ & TP3E2 & $18,27 \mathrm{de}$ & $-5,48$ \\
\hline 44 & TL3E2.1 & 27,45 cdef & $-14,11$ & TP4E5 & $18,18 \mathrm{de}$ & $-5,95$ \\
\hline 45 & TP1E2 & 27,43 cdef & $-14,17$ & PK1E & $18,14 \mathrm{de}$ & $-6,16$ \\
\hline 46 & LL1E3 & 27,23 cdef & $-14,80$ & LL1E3 & $17,99 \mathrm{de}$ & $-6,93$ \\
\hline
\end{tabular}


Tabel 4. lanjutan

\begin{tabular}{|c|c|c|c|c|c|c|}
\hline 47 & RD1E2 & 27,21 cdef & $-14,86$ & STP1E4 & $17,88 \mathrm{de}$ & $-7,50$ \\
\hline 48 & TP2E1.2 & 26,57 cdef & $-16,86$ & TL3E2.1 & $17,72 \mathrm{de}$ & $-8,33$ \\
\hline 49 & TL1E2.3 & 26,04 cdef & $-18,52$ & BD1E1 & $17,68 \mathrm{de}$ & $-8,54$ \\
\hline 50 & $\mathrm{BD} 2.1 \mathrm{E} 1$ & 25,99 cdef & $-18,68$ & BD1.2E2 & $17,51 \mathrm{de}$ & $-9,42$ \\
\hline 51 & $\mathrm{BD} 2.2 \mathrm{E} 3$ & 25,92 cdef & $-18,90$ & TL1E4 & $17,42 \mathrm{de}$ & $-9,88$ \\
\hline 52 & JB1E & 25,79 cdef & $-19,31$ & BD2.2E6 & $17,27 \mathrm{de}$ & $-10,66$ \\
\hline 53 & PU2E1 & 25,52 cdef & $-20,15$ & $\mathrm{BD} 2.2 \mathrm{E} 1$ & $17,00 \mathrm{de}$ & $-12,05$ \\
\hline 54 & STP1E3 & 24,95 cdef & $-21,93$ & JB1E & $16,98 \mathrm{de}$ & $-12,16$ \\
\hline 55 & LKE3 & 24,89 cdef & $-22,12$ & BD3.1E1 & $16,86 \mathrm{de}$ & $-12,78$ \\
\hline 56 & SN1E3 & 24,63 cdef & $-22,93$ & TL3E1.2 & $16,86 \mathrm{de}$ & $-12,78$ \\
\hline 57 & $\mathrm{BD} 1.2 \mathrm{E} 2$ & $24,18 \mathrm{def}$ & $-24,34$ & TL1E1 & $16,84 \mathrm{de}$ & $-12,88$ \\
\hline 58 & TL3E2 & 24,09 def & $-24,62$ & LKE3 & $16,76 \mathrm{de}$ & $-13,30$ \\
\hline 59 & LKE & $23,71 \mathrm{def}$ & $-25,81$ & BD2.1E1 & $16,73 \mathrm{de}$ & $-13,45$ \\
\hline 60 & $\mathrm{BD} 2.2 \mathrm{E} 1$ & 23,54 def & $-26,35$ & LL1E2 & $16,66 \mathrm{de}$ & $-13,81$ \\
\hline 61 & SN1E2 & $23,08 \mathrm{def}$ & $-27,78$ & TL1E2.3 & $16,56 \mathrm{de}$ & $-14,33$ \\
\hline 62 & SN2E3 & 23,08 def & $-27,78$ & $\mathrm{SS} 2 \mathrm{E}$ & $16,40 \mathrm{de}$ & $-15,16$ \\
\hline 63 & BD4.1E2 & 22,62 def & $-29,22$ & BD1.3E3 & $16,28 \mathrm{de}$ & $-15,78$ \\
\hline 64 & TL2E1 & $22,51 \mathrm{def}$ & $-29,57$ & TL3E2 & $16,20 \mathrm{de}$ & $-16,19$ \\
\hline 65 & TP3E2 & 22,39 def & $-29,94$ & TP3E1 & $16,17 \mathrm{de}$ & $-16,35$ \\
\hline 66 & TP4E1.2 & $22,29 \mathrm{def}$ & $-30,26$ & RD1E1 & $15,90 \mathrm{e}$ & $-17,74$ \\
\hline 67 & TP4E5 & $22,15 \mathrm{def}$ & $-30,69$ & BD1.1E2 & $15,79 \mathrm{e}$ & $-18,31$ \\
\hline 68 & SS2E & $21,01 \mathrm{def}$ & $-34,26$ & TP4E1.2 & $15,61 \mathrm{e}$ & $-19,24$ \\
\hline 69 & BD1.1E2 & 20,96 def & $-34,42$ & LKE2 & $15,36 \mathrm{e}$ & $-20,54$ \\
\hline 70 & SN2E & 20,89 def & $-34,64$ & BD4E1 & $15,36 \mathrm{e}$ & $-20,54$ \\
\hline 71 & TP3E1 & 20,64 def & $-35,42$ & TL1E2.1 & $15,32 \mathrm{e}$ & $-20,74$ \\
\hline 72 & PU1E2 & $20,61 \mathrm{def}$ & $-35,51$ & BD3E1 & $15,06 \mathrm{e}$ & $-22,09$ \\
\hline 73 & TL1E4 & $20,34 \mathrm{def}$ & $-36,36$ & ULG1E1 & $14,89 \mathrm{e}$ & $-22,97$ \\
\hline 74 & BD2E1 & $19,98 \mathrm{def}$ & $-37,48$ & BD4.1E2 & $14,64 \mathrm{e}$ & $-24,26$ \\
\hline 75 & TL3E1 & 19,76 def & $-38,17$ & SN1E2 & $13,75 \mathrm{e}$ & $-28,87$ \\
\hline 76 & BD1E1 & $19,73 \mathrm{def}$ & $-38,27$ & SN2E3 & $13,75 \mathrm{e}$ & $-28,87$ \\
\hline 77 & BD4E1 & $19,31 \mathrm{def}$ & $-39,58$ & SN2E & $13,68 \mathrm{e}$ & $-29,23$ \\
\hline 78 & BD3E1 & 19,09 def & $-40,27$ & PU1E2 & $13,62 \mathrm{e}$ & $-29,54$ \\
\hline 79 & BD3.1E1 & 18,29 ef & $-42,77$ & LKE & $13,58 \mathrm{e}$ & $-29,75$ \\
\hline 80 & SN1E & 17,34 ef & $-45,74$ & TL3E1 & $13,07 \mathrm{e}$ & $-32,38$ \\
\hline 81 & RD1E1 & 17,16 ef & $-46,31$ & TP1E2 & $13,06 \mathrm{e}$ & $-32,44$ \\
\hline 82 & ULG1E1 & 17,12 ef & $-46,43$ & SN1E & $12,62 \mathrm{e}$ & $-34,71$ \\
\hline 83 & LKE2 & $14,14 \mathrm{f}$ & $-55,76$ & $\mathrm{BD} 2 \mathrm{E} 1$ & $12,46 \mathrm{e}$ & $-35,54$ \\
\hline
\end{tabular}

Angka-angka pada lajur yang sama yang diikuti oleh huruf kecil yang sama tidak berbeda nyata menurut uji jarak berganda Duncan pada $\alpha=0,05$.

berat kering $29,12 \mathrm{~g}$ (peningkatan 50,65\%), dan isolat JB1E3 berat basah $42,78 \mathrm{~g}$ (peningkatan $33,85 \%$ ) berat kering 33,01 g (peningkatan 70,77\%). Tidak semua isolat mampu meningkatkan hasil bawang merah karena ada beberapa isolat yang hasilnya negatif (tidak mampu meningkatkan hasil dibandingkan kontrol).

Kemampuan meningkatkan hasil tanaman oleh kelompok bakteri endofit telah dilaporkan, antara lain Harish et al. (2009) melakukan penelitian pengaruh bioformulasi campuran isolat Pseudomonas fluorescens (Pf1) dan Bacillus sp. (EPB 22) pada pisang meningkatkan hasil secara signifikan $(53,33 \%)$ dibandingkan kontrol. Bioformulasi tersebut juga mempunyai potensi sebagai penginduksi ketahanan pisang terhadap Bunchy Top Virus. Bakteri endofit yang dapat memacu pertumbuhan merupakan salah satu alternatif untuk mengurangi pengunaan bahan kimia pada pertanian (Kloepper, 1993). 
Tabel 5: Hasil analisis BLAST isolat endofit yang mampu menekan serangan Xaa

\begin{tabular}{cllcc}
\hline No & Kode & \multicolumn{1}{c}{ Identitas } & Kode aksesi GenBank & \% kesamaan \\
\hline 1 & BD42E1 & $\begin{array}{l}\text { Bacillus cereus strain P14 16S ribosomal } \\
\text { RNA gene, partial sequence } \\
\text { Bacillus sp. H1(2008) 16S ribosomal RNA } \\
\text { gene, partial sequence }\end{array}$ & JN700160 & 99 \\
3 & SN1Ecillus cereus strain Se07 16S ribosomal & JN700112.1 & 98 \\
4 & PN2E2 & $\begin{array}{l}\text { RNA gene, partial sequence } \\
\text { Bacillus sp. SJ1 16S ribosomal RNA gene, } \\
\text { partial sequence }\end{array}$ & GQ258753 & 83 \\
5 & UL61E2 & $\begin{array}{l}\text { Serratia marcescens strain PPM4 16S } \\
\text { ribosomal RNA gene, partial sequence } \\
\text { Serratia marcescens strain PPM4 16S } \\
\text { ribosomal RNA gene, partial sequence }\end{array}$ & JQ308604.1 & 96 \\
6 & JBE3 & JQ308604.1 & 96 \\
\hline
\end{tabular}

Identifikasi Isolat Endofit. Enam isolat terpilih dengan efektifitas penekanan penyakit HDB dan efektifitas peningkatan hasil yang tinggi (BD4.2E1, SN1E4, PU2E2, SN2E2, ULG1E2 dan JB1E3) diidentifikasi secara molekular. Amplifikasi DNA 6 isolat terpilih menghasilkan pita berukuran $\pm 1300 \mathrm{bp}$. Setelah dilakukan sekuensing terhadap asam nukleat dan dilanjutkan dengan analisa BLAST didapatkan identitas isolat terbaik tersebut seperti pada Tabel 5.

Hasil analisis BLAST isolat ULG1E2 dan JB1E3 memiliki kemiripan 96\% dengan Serratia marcescens strain PPM4 16S, isolat BD4.2E1 memiliki kemiripan 99\% dengan Bacillus cereus strain P14, isolat SN2E2 memiliki kemiripan 96\% dengan Bacillus cereus strain Se07, Isolat SN1E4 memiliki kemiripan 98\% dengan Bacillus sp. H1 dan isolat PU2E2 memiliki kemiripan 83\% dengan Bacillus sp. SJ1.

Mekanisme penekanan penyakit dari tiga bakteri endofit yaitu Bacillus cereus (BD4.2E1), Bacilles sp. HI (SN1E4), Serratia marcescen PPM 4 (JB1E3) dan Bacillus sp. SJ1 (PU2E2) bersifat tidak langsung berupa induksi ketahanan. Bakteri endofit diintroduksikan pada benih sehingga dapat melindungi tanaman pada saat patogen masuk. Hallman et al. (2000) menyatakan strain bakteri endofit dari awal dapat mengkolonisasi jaringan kortek akar dan merangsang pertahanan tanaman. Sifat terpenting bagi bakteri endofit untuk mampu sebagai agen pengendali hayati adalah kemampuan kolonisasi yang cepat pada jaringan inang. Kelompok Bacillus spp seperti $B$. cereus, $B$. amyloliquefaciens, B. substilis, B. pasteurii, $B$. pumilus, $B$. mycoides, dan $B$. sphaericus dapat menekan insidensi dan severitas dari berbagai penyakit pada berbagai tanaman. Mekanisme yang terjadi pada menekanan penyakit tersebut adalah induksi ketahanan sistemik (Induced Systemic Resistance $=$ ISR) (Kloepper et al., 2004). Bakteri antagonis Serratia marscescens strain B2 mampu menginduksi ketahanan tanaman padi terhadap penyakit blast yang disebabkan Pyricularia oryzae (Someya et al., 2002).

Bakteri endofit terpilih yang mampu meningkatkan hasil bawang merah adalah dari kelompok Bacillus cereus $\mathrm{Se} 07$ (SN2E2), Serratia mercescens PPM4 (ULG1E2) dan Bacillus sp. SJI (PU2E2). Bakteri Bacillus cereus $\mathrm{Se} 07$ bahkan mampu meningkatkan rata-rata berat kering dan berat basah lebih dari $200 \%$ (Tabel 4). Bakteri endofit dapat meningkatkan pertumbuhan dan hasil melalui banyak cara, termasuk aktivitas melarutkan fospat, produksi fitohormon IAA, dan memproduksi siderophor (Jalgaonwala \& Mahaja, 2011). Bakteri Bacillus megaterium, Micrococcus luteus, Bacillus cereus, dan Lysinibacillus fusiformis mempunyai peranan dalam peningkatan pertumbuhan tanaman gingseng (Vendan et al., 2010).

\section{SIMPULAN}

Berdasarkan hasil penelitian ini dapat disimpulkan bahwa, enam isolat bakteri endofit terpilih yaitu isolat BD4.2E1, SN1E4, SN2E2, PU2E2, JB1E3, dan ULG1E2 mampu menekan serangan penyakit HDB dan meningkatkan hasil bawang merah dengan efektivitas penekanan persentase penyakit tertinggi $65,06 \%$ (BD4.2E1) dibandingkan kontrol. Isolat SN2E2 mampu meningkatkan hasil bawang merah dengan peningkatan berat kering $214,85 \%$ dibandingkan 
kontrol. Hasil identifikasi berdasarkan sekuensing 16 rRNA. Keenam isolat terpilih tersebut adalah Bacillus cereus stain P14, Bacillus cereus strain Se07, Basillus sp. H1, Bacillus sp. SJ1 and Serratia marcescens strain PPM4.

\section{DAFTAR PUSTAKA}

Badan Pusat Statistik (BPS). 2013. Data Produksi Tanaman sayuran 2012. BPS

Centre for Microbial and Plant Genetics. 2006. Plant growth promoting rhizobacteria dan biodegradasi. Katolike Universiteit Leuwen, Netherland.

Compant SRB, Sessitsch A, Nowak J, Clement C, \& Barka EA. 2005. Endophytic colonization of Vitis vinifera L. by plant growth-promoting bacterium Burkholderia sp.strain PsJN. Appl. Environ. Microbiol. 71: 1685-1693.

Gent DH \& Schwartz HF. 2005. Management of Xanthomonas leaf blight of onion with a plant activator, biological control agents and copper bactericides. Plant Dis. 89: 631-639.

Habazar T, Nasrun, Jamsari, Rusli I. 2007. Pola penyebaran penyakit hawar daun bakteri (Xanthomonas axonopodis pv allii) pada bawang merah dan upaya pengendaliannya melalui imunisasi menggunakan rhizobacteria. Laporan hasil penelitian KKP3T. Universitas Andalas bekerjasama dengan Sekretariat Badan Penelitian dan Pengembangan Pertanian.

Hallman J, Halmann AQ, Miller WG, Sikora RA, \& Lindow SE. 2000. Endophytic colonization of plants by the biocontrol agent Rhizobium etli G12 in relation to Meloidogyne incognita infection. Phytopathol. 91: 415-422.

Hallmann J, Hallmann AQ, Mahaffee WF, \& Kloepper JW. 1997. Bacterial endophytes in agricultural crops. Can. J. Microbiol. 43: 895-9214.

Harish S, Kavino M, Kumar N, Balasubramanian P, \& Samiyappan R. 2009. Induction of defense-related proteins by mixtures of plant growth promoting endophytic bacteria against Banana bunchy top virus. Biol. Control. 51: 16-25.

Jalgaonwala RE \& Mahaja RT. 2011. Isolation and characterization of endophytic bacteria from roots of Pongamia glabra Vent. Int. J. Pharma and Bio Sci. 1: 280-287.
Klement Z, Rudolph K, \& Sand DC. 1990. Methode in phytobacteriology. Academic Kiado. Budapest.

Kloepper JW, Ryu CM, \& Zhang S. 2004. Induced systemic resistance and promotion of plant growth by Bacillus spp. Phytophatol. 94: 12591266.

Kloepper JW. 1993. Plant growth-promoting rhizobzcteria as biocontrol agents. In: Metting FB Jr (ed) soil microbial ecology-applications in agricultural and environmental management. Marcel Dekker, Inc., New York, pp 255-274.

Kumar HB. 2005. Effect of Pseudomonas flourescent on bean common mosaic potyvirus incidence in French Bean . Int. J.of Botany 1(2): 163-167.

Paulraj L \& O'Garro LW. 1993. Leaf blight of onion in Barbados caused by Xanhomonas campestris. Plant Dis. 77: 198-201.

Reiter B, Preifer U, Schwab H, \& Sessitsch A. 2002. Respone of endophytic bacteria communities in potato plants to infection with Erwinia caratovora subsp. atroseptica. Appl. Environ. Microbiol. 68: 2261-2268.

Resti Z, Yanti Y, \& Rahma H. 2007. Distribusi penyakit hawar daun bakteri pada tanaman bawang (Xanthomonas axonopodis pv allii) sebagai penyakit baru di Sumatera Barat. Laporan Penelitian DIPA Unand. Universitas Andalas. Padang.

Sanger F, Nicklen S, \& Coulson AR. 1997. DNA Sequensing with Chain Terminating Inhibitor. Proc. Natl. Acad. Sci.USA. 74: 5463-5467.

Schaad NW \& Stall RE. 2001. Xanthomonas. Pages 82194 in Laboratory Gurde for Identification of Plant Phatology Bacteria Z.nd.ed.N.W. Scaad ed. American Phytopathologjcal Society, ST. Paul. M.N.

Schwartz HF \& Gent DH. 2006. Xanthomonas Leaf Blight of Onion (http//www.Extcolestate.edu/ push/gorden html access 22-02-2006).

Someya N, Makajima M, Hilon T, Yamaguchi I, \& Akutsu K. 2002. Induced resisntance to rice blast by antagonistic bacterium Serratia marcescen strain B2. Plant Pathol. 68: 177-182.

Strobel GA, Stierle A, Stierle D, \& Hess WM. 1993, Taxomyces andreanae a proposed new taxon for a bulbilliferous hyphomycete associated with Pacific yew. Mycotaxon., 47: 71-78. 
Vendan RT, Joon Y, Heelee S, \& Ha Rhee Y. 2010. Diversity of endophytic bacteria in gingseng and their potential for plant growth promotion. Microbiological Society of Korea 48(5): 559-565.
Zinniel DK, Lambrecht P, Harris NB, Feng Z, Kaczmarski D, Higley $\mathrm{P}$, Ishimaru CA, Arunakumari A, Barletta RG, \& Vidaver AK. 2002, Isolation and characterization of endophytic colonizing bacteria from agronomic crops and prairie plants. Appl. Environ. Microbiol. 68: 21982208. 